\title{
Wczesne rozpoznawanie zaburzeń ze spektrum autyzmu - symptomy ryzyka, diagnoza wstępna, badania przesiewowe
}

\begin{abstract}
Barbara Winczura, Wczesne rozpoznawanie zaburzeń ze spektrum autyzmu symptomy ryzyka, diagnoza wstęna, badania przesiewowe [Early detection of autism spectrum disorders - risk symptoms, initial diagnosis, screening]. Interdyscyplinarne Konteksty Pedagogiki Specjalnej, nr 22, Poznań 2018. Pp. 73-103. Adam Mickiewicz University Press. ISSN 2300-391X. DOI: https://doi.org/10.14746/ikps.2018.22.05

The diagnosis of autism within the first two years of a child's life is burdened by many difficulties. The most significant symptoms for early recognition of ASD are deemed to be emotional and social deficits, disturbances in the development of speech and communication as well as atypical behaviour in the form of limited, repetitive behaviour patterns. In the first as well as the second year of life, the most commonly confirmed early signs of ADS refer to the lack of behaviour indicating the child's readiness to form social relations and to social communication, including in particular its reactions to its own name, limited eye contact, atypical facial expressions in social situations, the lack of emotional adaptation, limited interest in social impulses and poor vocalisation, as well as limited abilities to imitate, establish a common field of attention and the expression of attachment to the next of kin. In the second year of age, the atypical behaviour is manifested more clearly and may, although it must not necessarily, shine through in all areas typical for autism.
\end{abstract}

KEY WORDS: autism spectrum disorders, autism risk symptoms, social communication and general communication disturbances, stereotypical, limited behaviour patterns, early detection of autism, initial diagnosis, screening tests 


\section{Wprowadzenie}

Pomimo że wiele dzieci ze spektrum autyzmu (Autism Spectrum Disorder - ASD) ma podobne cechy charakterystyczne dla tego zaburzenia, to $\mathrm{w}$ rezultacie cechuje je duża rozbieżność ujawnianych umiejętności oraz dynamika zmian. Zamiany rozwojowe wpływają na ekspresję symptomów ${ }^{1}$. Kategoryzacja i diagnoza nozologiczna dziecka jako autystycznego jest dość skomplikowana. Szczególnie $\mathrm{z}$ powodu różnic $\mathrm{w}$ zakresie specyficznych objawów, które mogą u poszczególnych dzieci różnić się intensywnością i stopniem natężenia². Zarówno objawy osiowe, jak i te wtórne mogą wyrażać się odmiennie i występować w różnych kombinacjach ${ }^{3}$. Znacznym utrudnieniem jest także niejednorodny czas wystąpienia pierwszych symptomów (od urodzenia do 36. miesiąca życia), ich liczba oraz nasilenie w czasie, okoliczności w jakich najczęściej się pojawiają (w tym wpływ czynników środowiskowych), a także ogólny rozwój psychofizyczny dziecka, często zdeterminowany przez zaburzenia współwystępujące (współchorobowość) oraz upośledzenie umysłowe ${ }^{4}$. Według ostatnich danych $70 \%$ osób ze spektrum autyzmu może mieć jedno zaburzenie współistniejące, a 40\% w tej populacji dwa lub więcej zaburzeń dodatkowych ${ }^{5}$. Mimo neurobiologicz-

${ }^{1}$ E. Pisula, Autyzm. Przyczyny, symptomy, terapia, Wydawnictwo Harmonia, Gdańsk 2010, s. 73.

2 A.J. Cotugno, Terapia grupowa dla dzieci z zaburzeniami ze spectrum autyzmu. Rozwijanie kompetencji i umiejętności społecznych, Wydawnictwo Fraszka Edukacyjna, Warszawa 2011, s. 13.

${ }^{3}$ M. Piszczek, Kwestionariusz oceny kompetencji emocjonalno-społecznej (KOKE-S) wysoko funkcjonujących autystów i dzieci z zespołem Aspergera (część pierwsza), "Rewalidacja. Czasopismo dla nauczycieli i terapeutów" 2010, nr 1(27), s. 48.

4 J. Błeszyński, Autyzm a niepetnosprawność intelektualna i opóźnienie w rozwoju. Skala Oceny Zachowań Autystycznych, Wydawnictwo HARMONIA UNIWERSALIS, Gdańsk 2011, s. 57; B. Winczura, Autyzm, autyzm atypowy a schizofrenia wczesnodziecięca, [w:] Dzieci z zaburzeniami łączonymi. Trudne ścieżki rozwoju, red. B. Winczura, Oficyna Wydawnicza „Impuls”, Kraków 2012, s. 86.

${ }^{5}$ Diagnostic and statistical manual of mental disorders. Fifth edition, (DSM-5), American Psychiatric Association, APA, Washington DC 2013. 
nego podłoża zaburzeń ze spektrum autyzmu, nadal nie ustalono biologicznych markerów, które pozwalałyby na wykorzystywanie ich w codziennej diagnozie klinicznej. Rozpoznanie stawiane jest na podstawie charakterystycznego dla ASD obrazu klinicznego, ustrukturyzowanego wywiadu, w celu potwierdzenia lub wykluczenia ewentualnych chorób współistniejących, a także dodatkowych badań biochemicznych, genetycznych i obrazowych. Choć żadne z owych badań pojedynczo nie może stanowić o diagnozie końcowej zaburzenia ze spektrum autyzmu6. Pomimo wielu badań nad dynamiką rozwoju zaburzeń ze spektrum autyzmu, dysponujemy niewielką wiedzą na temat rozwoju dzieci z ASD w ciągu pierwszych miesięcy życia. Wczesna ocena zaburzeń u małych dzieci ma zwykle charakter introspektywny i opiera się najczęściej na informacjach uzyskanych od rodziców/bliskich opiekunów tych dzieci. Chociaż opinie te zwykle bywają trafione, wręcz precyzyjnie określone, to trudno ustalić, czy zawsze oddają obiektywny stan rzeczy. Podejmowane są liczne badania mające na celu ustalenie kryteriów możliwie trafnego rozpoznawania ryzyka zaburzeń ze spektrum autyzmu we wczesnym okresie rozwoju dziecka. Niezależnie od faktu, że objawy ASD pojawiają się w ciągu pierwszych dwóch lat życia dziec$\mathrm{ka}$, to dowody dotyczące czasu występowania początkowych objawów oraz ich charakteru, natężenia pozostają nadal ograniczone ${ }^{7}$.

\section{Wczesne symptomy zaburzeń ze spektrum autyzmu}

Według klasyfikacji DSM-5 do postawienia diagnozy zaburzeń ze spektrum autyzmu wymagane jest występowanie klinicznych objawów ASD we wczesnym okresie życia, ale ich brak w okresie póź-

${ }^{6}$ A. Rynkiewicz, M. Kulik, Wystandaryzowane, interaktywne narzędzia do diagnozy zaburzeń ze spektrum autyzmu, a nowe kryteria diagnostyczne DSM-5, "Psychiatria” 2013, 10, nr 2, s. 42.

${ }^{7}$ M. Skórczyńska, Wczesne diagnozowanie autyzmu - perspektywy i dylematy, [w:] Autyzm Na granicy zrozumienia, red. B. Winczura, Oficyna Wydawnicza "Impuls”, Kraków 2009, s. 56; E. Pisula, Autyzm. Przyczyny..., s. 81. 
niejszym nie wyklucza rozpoznania $\mathrm{ASD}^{8}$. Badania pokazują że pierwsze objawy autyzmu są zauważalne pomiędzy 6. a 12. miesiącem życia. Większość dzieci, u których z czasem zdiagnozowano ASD, nawiązuje jeszcze w 6. miesiącu życia relatywnie prawidłowy kontakt wzrokowy i prezentuje uśmiech społeczny, jednak ich częstotliwość i jakość zmniejszają się w okresie od 6. do 12. miesiąca życia9. W okresie tym pojawiają się też takie objawy, jak: brak prawidłowej reakcji na własne imię, brak współgrania emocjonalnego z innymi osobami, nieokazywanie przywiązania, zubożała wokalizacja, zachowania stereotypowe, nietypowe reakcje na bodźce sensoryczne, nietypowa eksploracja przedmiotów. Może także wystąpić zatrzymanie lub regres w rozwo$\mathrm{ju}^{10}$. Za kluczowe obszary dla wczesnego rozpoznawania ASD uznaje się trudności w kontaktach społecznych i komunikowaniu się, a także specyficzne, ograniczone powtarzające się zachowania, co pozostaje w korelacji z kryteriami diagnostycznymi według DSM-511.

\section{Trudności w nawiązywaniu relacji społecznych}

Większość obserwacji wskazuje, że początki rozwoju emocjonalno-społecznego $\mathrm{u}$ małych dzieci z podejrzeniem autyzmu moga być zaburzone, choć też wysoce zróżnicowane. U niektórych z nich zaburzenia zdolności nawiązywania kontaktu emocjonalnego można zaobserwować już przed ukończeniem przez nie 6. miesiąca życia. Pomiędzy dzieckiem a bliskimi nie dochodzi do wymiany dostosowanych treściowo działań społecznych oraz komunikatów werbalnych i niewerbalnych ${ }^{12}$. Szczególne nieprawidłowości wi-

${ }^{8}$ L. Meng-Chuan, M. V. Lombard, B. Chakrabarti, S. Baron-Cohen, Subgrouping the Autism "Spectrum": Reflections on DSM-5. PLOS Biology, 2013, 11 (4), s. 1-7.

${ }^{9}$ A. Steiner, T. R. Goldsmith, A. V. Snow, K. Chawarska, Practitioner's Guide to Assessment of Autism Spectrum Disorders in Infants and Toddlers, "Journal of Autism and Developmental Disorders" 2012, 42 (6), s. 1184.

10 A. Rynkiewicz, M. Kulik, op. cit., s. 42.

11 Diagnostic and statistical manual of mental disorders. Fifth edition, (DSM-5), 2013

12 E. Pisula E., Małe dziecko z autyzmem, diadnoza i terapia, Gdańskie Wydawnictwo Psychologiczne, Gdańsk 2005, s. 32. 
doczne są w obszarze komunikacji społecznej, a głównie jej niewerbalnych aspektów. Do najwcześniejszych objawów (zwiastunów) zaburzeń ze spektrum autyzmu należą:

- ubogi kontakt wzrokowy (zaburzenie pojawia się przed 6. miesiącem życia),

- brak zainteresowania ludźmi, ignorowanie ich, krótki czas patrzenia na ludzi (zaburzenie pojawia się około 1. roku życia),

- brak zdolności do naprzemiennego uczestnictwa w interakcjach oraz ograniczone zdolności inicjowania i podtrzymywania interakcji (zaburzenie pojawia się przed 6. miesiącem życia),

- brak reakcji na komunikaty rodzica kierowane do dziecka (zaburzenie pojawia się przed 6. miesiącem życia),

- brak reagowania uśmiechem w sytuacjach społecznych i innych form okazywania radości (przed 6. miesiącem życia),

- brak emocjonalnego dostrojenia, emocjonalnej synchronii, brak dostosowania mimiki do sytuacji (zaburzenie pojawia się przed 6. miesiącem życia),

- brak reakcji na własne imię (zaburzenie pojawia się między 8. a 10. miesiącem życia),

- brak wskazywania (zaburzenie pojawia się między 8. a 12. miesiącem życia),

- brak domagania się, by być branym na ręce i przytulanym (zaburzenie pojawia się po 6. miesiącu życia),

- brak podążania wzrokiem za osobą, przedmiotem (zaburzenie pojawia się na przełomie 1. i 2. roku życia),

- brak złożonych zachowań społecznych łączących spojrzenie, ekspresję mimiczną, ton głosu i gestykulację (zaburzenie pojawia się po 6. miesiącu życia),

- brak rozumienia gestów o znaczeniu społecznym (np. „pa, pa") (zaburzenie pojawia się na przełomie 1. i 2. roku życia) (Baranek, Volkmar, Chawarska i Klin; Maestro, Muratori, Cesari, Pecini, Apicella, Stern) ${ }^{13}$.

${ }^{13}$ E. Pisula, Od badań mózgu do praktyki psychologicznej AUTYZM, Wydawnictwo GWP, Sopot 2012. 
Julie A. Osterling i Geraldine Dawson w swoich obserwacjach wyodrębniły cztery charakterystyczne zachowania, w zakresie których ponad $90 \%$ dzieci z autyzmem w wieku 12 miesięcy różniło się od 10-miesięcznych niemowląt rozwijających się prawidłowo oraz od dzieci 12-miesięcznych z opóźnieniem w rozwoju. Zaliczyły do nich:

- brak patrzenia w stronę innych osób,

- brak reakcji na własne imię,

- brak wskazywania, brak pokazywania lub podawania przedmiotów ${ }^{14}$.

Podobne wyniki pozyskano $\mathrm{w}$ badaniach prowadzonych przez Grace T. Baranek ${ }^{15}$. Do dyskretnych symptomów autyzm u niemowląt w okresie między 9. a 12. miesiącem życia zaliczono:

- słabą orientację wzrokową (także bodźców niespołecznych),

- opóźnioną reakcję na własne imię,

- unikanie bycia dotykanym przez inną osobę.

Do niepokojących zachowań dziecka w 1. roku życia, które mogą być silnie powiązane z późniejszym rozpoznaniem autyzmu zalicza się:

- obniżoną reaktywność społeczną, (np. reagowanie na imię, patrzenie na ludzi, zachowania związane $\mathrm{z}$ tworzeniem wspólnego pola uwagi),

- nietypowe zachowania związane z regulacją sensoryczną (np. częste wkładanie przedmiotów do ust, niezwykłe wzorce uwagi wzrokowej, zwiększona drażliwość) ${ }^{16}$.

Za najbardziej diagnostyczny wskaźnik uznano brak patrzenia na innych ludzi i brak reakcji dziecka na własne imię. Problem ten

14 J. Osterling, D. Dawson, Early recognition of children with autism: A study of first brithday home videotapes, "Journal of Autism and Developmental Disorders" 1994, 24, s. 250.

15 G.T. Baranek, Autism during infancy: a retrospective video analysis of sensory motor and social behaviors at 9-12 moths of age, "Journal of Autism and Developmental Disorders" 1999, vol. 29, no. 3, s. 220.

16 Diagnoza zaburzeń ze spektrum autyzmu, red. S. Goldstein, J.A. Naglieri, S. Ozonoff, Wydawnictwo Uniwersytetu jagiellońskiego, Kraków 2017, s.162. 
zauważają także rodzice, ponieważ przyczynia się on do trudności w komunikacji społecznej $\mathrm{z}$ dzieckiem. W przypadku reakcji na imię można zaobserwować, iż musi ono zostać wielokrotnie powtórzone, zanim dziecko zwróci uwagę na wypowiadającą je osobę. Takie opóźnienie, a czasem nawet zupełny brak reakcji, uważa się za jeden z sygnałów informujących o możliwym zagrożeniu autyzmem już u dzieci 8-, 9-miesięcznych. Istotne jest również odkrycie, że już w 12. miesiącu życia między dziećmi z grupy ryzyka autyzmu a rozwijającymi się prawidłowo widoczne są różnice w złożonych zachowaniach komunikacyjnych - takich jak łączenie gaworzenia i wskazywania albo wypowiadanie słów i wskazywanie ${ }^{17}$.

Pod koniec 1. roku życia można zauważyć także brak zabaw związanych z naśladowaniem (np. zabawa w „a kuku”, robienie „pa, pa” na pożegnanie). Ma to ścisły związek z nieumiejętnością naśladowania gestów i zaburzonym rozwojem umiejętności społecznych u dziecka ${ }^{18}$. Zauważono, że dzieci te sprawiają wrażenie niezainteresowanych czy też nieświadomych interpersonalnych aspektów relacji z innymi ludźmi. Nawet jeżeli dają się angażować $\mathrm{w}$ pewne rodzaje aktywności, to i tak przyjmują $\mathrm{w}$ nich bierną postawę ${ }^{19}$. Nie obserwują tego, co robią inni. Nie są zainteresowane czynnościami, które wykonują inni. Nie naśladują zachowań innych, gdyż nie są świadome tego, co dzieje się z innymi ludźmi. Nie dzielą się z nimi swoimi zainteresowaniami, pragnieniami ${ }^{20}$.

17 E. Werner, G. Dawson, J. Munson, J. Osterling, Variation in early developmental course in autism and its relations with behavioral outcome at 3-4 years of age, "Journal of Autism and Developmental Disorders" 2005, 35, s. 340-348.

18 G. Jagielska, Objawy autyzmu dziecięcego, [w:] Autyzm i zespót Aspergera, red. J. Komender, G. Jagielska, A. Bryńska, Wydawnictwo Lekarskie PZWL, Warszawa 2009, s. 33-50.

19 Pisula E., Autyzm - fakty, wattpliwości, opinie, Wydawnictwo WSPS, Warszawa 1993.

${ }^{20}$ B. Blok, Z. Brzeska, B. Ignaczewska, Diagnoza $i$ wspomaganie rozwoju dziecka $z$ autyzmem w Specjalnym Ośrodku Rewalidacyjno - Wychowawczym dla Dzieci i młodzie$\dot{z} y$ z Autyzmem, [w:] Wczesne wspomaganie rozwoju dziecka od chwili wykrycia niepetnosprawności do podjęcia nauki w szkole, red. T. Serafin, Ministerstwo Edukacji Narodowej i Sportu, Warszawa 2005, s. 171-198. 
W drugiej połowie 1 . roku życia u dzieci z grupy ryzyka spektrum autyzmu zaobserwowano także trudności $\mathrm{z}$ tworzeniem wspólnego pola uwagi. Przejawiają się one w ograniczonej zdolności dziecka do odbioru bodźców społecznych, braku zainteresowania ludźmi oraz braku reakcji, gdy ktoś woła dziecko po imieniu ${ }^{21}$. Niemowlęta z grupy ryzyka spektrum autyzmu nie podążają wzrokiem za palcem wskazującym rodzica, nawet jeżeli próbuje się dziecku pomóc zlokalizować kierunek spojrzenia poprzez fizyczną podpowiedź, np. dotykając ramienia dziecka przed pokazywaniem lub wołając po imieniu. Są dzieci, które w końcu popatrzą we wskazanym kierunku, ale bez wymiany spojrzeń z rodzicem i bez widocznej ekspresji emocjonalnej22. Nie potrafią ukierunkować uwagi innej osoby na określone obiekty lub zdarzenia, a także monitorować uwagi innej osoby oraz zwracać uwagi na to, co osoba chce pokazać23. Dzieci z autyzmem nie widzą związku między patrzeniem na coś, a pragnieniem posiadania tego, manipulowania tym z ciekawości. Trudności sprawia im odczytywanie treści informacji zawartych w kierunku patrzenia ${ }^{24}$.

Marian Sigman i in. ${ }^{25} \mathrm{w}$ wyniku obserwacji i prowadzonych badań wyłapali główne atypowe zachowania dziecka w rozwoju społecznym poniżej 18. miesiąca życia. Uznali, że są to sygnały ostrzegawcze dla wczesnego wykrywania autyzmu. Zaliczyli do nich:

- brak zdolności uczestniczenia w interakcjach społecznych,

- brak tworzenia wspólnego uwagi (wskazywania, podążania wzrokiem),

- ograniczoną zdolność naśladowania,

21 E. Pisula, Autyzm. Przyczyny, symptomy..., s. 85-87.

22 M. Skórczyńska, op. cit., s. 45-46.

23 E. Pisula, Autyzm u dzieci. Diagnoza, klasyfikacja, etiologia, Wydawnictwo naukowe PWN, Warszawa 1999.

${ }^{24}$ K. Markiewicz, Charakterystyka zmian w rozwoju umysłowym dzieci autystycznych, Wydawnictwo Uniwersytetu Marii Curie-Skłodowskiej, Lublin 2007, s. 96-99.

${ }^{25}$ M. Sigman, A. Dijamco, M. Gratier, A. Rozga, Early detection of core deficits in autism, "Mental Retardation and Developmental Disabilities Research Reviews" 2004, 10, 221-233. 
- zaburzone rozpoznawanie emocji i synchronię emocjonalną,

- ograniczenia w okazywaniu przywiązania.

Trudno na ogół powiedzieć, co tak dokładnie wywołuje w rodzinie pierwszy niepokój. Zazwyczaj obawy nasilają się dopiero wtedy, gdy zaczynają się mnożyć drobne spostrzeżenia, z których żadne samo w sobie nie wydaje się istotne. Uważna analiza rodzinnych nagrań wideo pokazała, że z perspektywy czasu subtelne z początku objawy stają się oczywiste, znacznie wyraźne już pod koniec 1. roku życia ${ }^{26}$. Pierwsze zaburzone umiejętności społeczne dziecka w kontakcie z matką są oceniane jako istotny sygnał zapowiadający rozwój autyzmu27. Do najczęściej zgłaszanych przez rodziców, niepokojących objawów natury emocjonalno-społecznej u małego dziecka należą:

- wysoka drażliwość emocjonalna,

- preferowanie samotności,

- ignorowanie innych osób, szczególnie najbliższych.

Dziecko nie wydaje się być zainteresowane kontaktem fizycznym z matką, wręcz broni się przed nią, odsuwa się od niej, a nawet ją demonstracyjnie odpycha28. Na ogół nie lubi zabaw z przytulaniem, baraszkowaniem. Istnieje duża grupa dzieci, które w żaden sposób nie pozwalają sobie na jakąkolwiek formę kontaktu fizycznego. Typowym problemem jest brak lub ograniczony kontakt wzrokowy, często określany jako tzw. „puste” spojrzenie. Dziecko jest w niewielkim stopniu zainteresowane twarzą ludzką, widokiem i głosem matki29. Nie fiksuje wzroku na twarzy matki, nie wodzi za jej wzrokiem, jego spojrzenie błądzi w przestrzeni, nie reaguje emo-

${ }^{26}$ U. Frith, Autyzm. Wyjaśnienie tajemnicy, Gdańskie Wydawnictwo Psychologiczne Gdańsk 2008, s. 32.

${ }^{27}$ H. Jaklewicz, Autyzm dziecięcy, [w:] Psychiatria wieku rozwojowego, red. A. Popielarska, M. Popielarska, Wydawnictwo Lekarskie PZWL, Warszawa 2000, s. 118.

28 E. Pisula, Wspomaganie osób z zaburzeniami należącymi do autystycznego spektrum w perspektywie psychopatologii rozwojowej, [w:] Psychologia rozwoju człowieka, red. J. Trempała, Wydawnictwo PWN, Warszawa 2011, s. 449.

${ }^{29}$ J. Błeszyński, Autyzm a niepetnosprawność intelektualna..., s. 61; D. Senator, Przejawy autyzmu w pierwszym roku życia, „Pediatria Polska” 2006, nr 2, s. 128. 
cjonalnym ożywieniem na jej widok, szczególnie na jej uśmiech czy gesty. Charakterystyczna jest zaburzona mimika twarzy („maskowatość"), brak ekspresji towarzyszącej spojrzeniu, rzadki uśmiech i typowa nieumiejętność przyjęcia postawy ciała, wyrażającej gotowość i pragnienie, aby ktoś wziął je na ręce ${ }^{30}$. Uśmiech społeczny pojawia się rzadko, czasami wygląda sztucznie, jakby był doklejony. Dziecko nie reaguje na wołanie po imieniu przy równoległym zwracaniu uwagi na inne dźwięki w otoczeniu ${ }^{31}$. Widocznym deficytem są także trudności z imitowaniem stanów emocjonalnych innych osób. Nie potrafi dzielić radości, smutku, bólu, strachu z innymi osobami. W sytuacjach zaniepokojenia, zagrożenia nie poszukuje u bliskich pocieszenia i nie oferuje go, a nawet sprawia wrażenie nieświadomego, że jest to w ogóle możliwe, ignoruje lub niewłaściwie interpretuje zachowania emocjonalne bliskich ludzi, nie okazuje troski o uczucia i emocje innych. Nie czyni rozróżnienia pomiędzy bliskimi osobami a przedmiotami, którymi się fascynuje. Zdecydowanie woli przebywać w świecie przedmiotów niż ludzi. Obserwuje się przy tym krótki czas patrzenia na ludzi ${ }^{32}$. Dziecko wcale albo rzadko przenosi spojrzenie z przedmiotu na twarz osoby. Badania, w których analizowano kierunek patrzenia, wskazują, że dzieci z tym zaburzeniem rzadziej patrzą $\mathrm{w}$ oczy oglądanych postaci, częściej natomiast śledzą ich poruszające się usta i resztę ciała ${ }^{33}$.

Obserwuje się także specyficzne, ograniczone formy nawiązywania kontaktów z ludźmi. Niektóre dzieci przyjmują dziwne pozy w kontakcie z innymi, np. stają zawsze bokiem, plecami do osoby stojącej blisko, uciekają od ludzi na znaczną odległość, mrużą oczy, zatykają uczy. Czasami, by nawiązać kontakt, posługują się znaczą-

${ }^{30}$ L. Wing, Zwiazek między zespołom Aspergera i autyzmem Kannera, [w:] Autyzm i zespót Aspergera, red. U. Frit, Wydawnictwo Lekarskie PZWL, Warszawa 2005, s. 117.

${ }^{31}$ D. Senator, op. cit., s. 129.

32 P. Randall, J. Parker, Autyzm. Jak pomóc rodzinie, Gdańskie Wydawnictwo Psychologiczne, Sopot 2010, s. 99, 146.

33 Pisula E., Wspomaganie osób z zaburzeniami..., s. 448. 
cymi dla siebie przedmiotami, np. klockiem, piłką, sznurkiem ${ }^{34}$. Typowy jest także brak ekspresji wokalno-emocjonalnej w rodzaju "ooo", „uu", znikomy lub nieobecny repertuar gestów interakcyjnych, np. machanie ręką "pa, pa” oraz brak właściwej gestykulacji i wyrażania emocji za pomocą postawy. W konsekwencji obserwujemy ograniczony repertuar zachowań społecznych, łączących spojrzenie, ekspresję mimiczną, ton głosu i gestykulację. Dziecko rzadko wymienia komunikaty z partnerem podczas wspólnej zabawy. Najczęściej preferuje samotną zabawę, bez kontaktu z ludźmi, zwykle o charakterze sensomotorycznym i/lub rytualnym ${ }^{35}$. Dziecko zwykle angażuje się $\mathrm{w}$ relacje dlatego, że chce zaspokoić swoje pragnienia, np. chce dostać zabawkę, smakołyk, często wykorzystując przy tym dłoń osoby stojącej obok (traktuje rękę dorosłego jako narzędzie, protezę do osiągniecia celu) ${ }^{36}$. Rodzice podają, że ich dziecko jest zbyt spokojne, ciche, wycofane z kontaktów, mało aktywne i niezainteresowane najbliższym otoczeniem ${ }^{37}$.

Analiza nagrań wideo z pierwszych urodzin dzieci, u których w późniejszym czasie rozpoznano autyzm, wykazała, że dzieci te różnią się od zdrowych rówieśników wieloma charakterystycznymi zachowaniami. Zaobserwowano głównie brak reakcji na własne imię, brak wskazywania protodeklaratywnego, nieobserwowanie twarzy innych osób, kiedy wskazują one na jakiś przedmiot. Z dużym ryzykiem występowania autyzmu u dziecka związane są zachowania ujawniające się w okresie od 18. do 24. miesiąca życia. Należą do nich:

- osamotnienie,

- brak zainteresowania dziećmi i naśladowania ich,

34 Pisula E., Małe dziecko z autyzmem..., s. 69.

35 Pisula E., Wspomaganie osób z zaburzeniami..., s. 449; E. Wiekiera, Strategia posteppowania z dziećmi autystycznymi, Przekład z "Engagement”, Poradnik praktyczny dla rodziców, Wydawnicwo Krajowe Towarzystwo Autyzmu Oddział w Krakowie, Kraków 1995, s. 13.

36 H. Jaklewicz, op. cit., s. 119.

37 E. Pisula E., Autyzm u dzieci. Diagnoza, klasyfikacja, etiologia, Wydawnictwo PWN, Warszawa 2000, s. 117. 
- brak wspólnie podzielanej uwagi i wskazywania protodeklaratywnego,

- brak przynoszenia i pokazywania rodzicom różnych obiektów, które zainteresowały dziecko,

- brak reakcji dziecka, kiedy jest wołane.

W jednym z badań prowadzonych przez S. Maestro, Filippo Muratori, Aallesia Cesari i in. wykazali, że 87\% dzieci, u których w późniejszym wieku rozpoznano autyzm, przejawiała wyraźnie owe nieprawidłowości w rozwoju i zachowaniu ${ }^{38}$.

Stopniowo, wraz z rozwojem u dziecka pojawiają się kolejne niepokojące objawy. Około 2. roku życia najczęściej sygnalizowane problemy przez rodziców/bliskich opiekunów dzieci, u których później diagnozuje się autyzm to: dziecko nie ma bliskich relacji $\mathrm{z}$ innymi $\mathrm{w}$ rodzinie, nie wita się, nie reaguje spontanicznie na rodzica, bliskiego opiekuna, gdy go widzi, słabo wyraża lub wcale nie wyraża emocji albo czyni to w sposób atypowy, nie posługuje się gestami w celu nawiązania kontaktów społecznych, nie umie inicjować zabawy z zabawkami, instruowane przez dorosłego potrafi bawić się przedmiotami, jednak rzadko robi to spontanicznie, nie interesuje się dziećmi lub nawet może ich unikać, nie reaguje na werbalne i niewerbalne próby nawiązywania z nim kontaktu, ma ograniczone zdolności naśladowania i nie uczestniczy w zabawach z udawaniem ${ }^{39}$, nie wyraża gotowości do wspólnych zabaw z dziećmi, nie jest zainteresowane zabawą społeczną przywiązanie do bliskich przybiera nietypową formę, głównie jako przywiązanie do rutyny, która jest związana z jakąś osobą, nie ma ono jednak oznak typowego przywiązania emocjonalno-społecznego ${ }^{40}$.

Dynamika przebiegu zaburzeń w rozwoju społecznym u dzieci z grupy ryzyka autyzmu wykazuje znaczną różnorodność i wielo-

38 G. Jagielska, op. cit., s. 42.

${ }^{39}$ E. Pisula E., Autyzm u dzieci..., s. 118; A. Wolski, Diagnoza autyzmu u matego dziecka - implikacje do pracy w rodzinie, „Rewalidacja. Czasopismo dla nauczycieli i terapeutów" 2010, nr 2(28), s. 24.

${ }^{40}$ E. Wiekiera, op. cit., s. 13; A.J. Cotugno, op. cit. 
postaciowość. Nie spotykamy dziecka, u którego występują wszystkie objawy, a z kolei ich niewielkie natężenie jeszcze nie musi oznaczać, że w przyszłości zostanie dziecku postawiona diagnoza ASD. Są także dzieci, u których objawy zaburzeń ze spektrum autyzmu są przysłonięte dodatkowymi problemami, np. deficytem uwagi, nadaktywnością psychoruchową, zaburzeniami lękowymi i innymi. Problemy diagnostyczne pojawiają się oczywiście w przypadkach granicznych. Jeśli dziecko charakteryzuje się niskim poziomem zdolności poznawczych, trudno jest określić, czy zaburzenia emocjonalno-społeczne odpowiadają jego wiekowi umysłowemu, czy też są większe niż w innych jego umiejętnościach rozwojowych ${ }^{41}$. Ponadto niektóre zachowania różniące małe dzieci z ASD od ich prawidłowo rozwijających się rówieśników są związane z upośledzeniem umysłowym lub zaburzeniem mowy. Pojawia się także coraz częściej grupa dzieci z łagodnymi objawami lub atypowymi cechami auty$\mathrm{zmu}^{42}$. Zaburzenia $\mathrm{w}$ sferze społeczno-emocjonalnej mają centralne znaczenie dla obrazu klinicznego zaburzeń ze spektrum autyzmu, przy czym manifestacja symptomów zmienia się wraz z wiekiem i rozwojem dziecka. Opóźnienia w zakresie umiejętności społecznych są silniejszymi predyktorami otrzymania diagnozy autyzmu niż opóźnienia w komunikowaniu się${ }^{43}$.

\section{Zaburzenia w rozwoju mowy i komunikowaniu się}

Jednym z najczęstszych wczesnych objawów u dzieci z podejrzeniem autyzmu są zaburzenia w rozwoju mowy i komunikowaniu się. Pierwszym krokiem diagnostycznym $w$ tej sferze jest ocena audiometryczna. Uszkodzenia słuchu częściej występują u dzieci, które znajdowały się na oddziałach intensywnej opieki noworodkowej. Testy przesiewowe noworodków pozwalają na wczesne wykrywanie obni-

\footnotetext{
${ }^{41}$ U. Frith, op. cit., s. 33.

${ }^{42}$ M. Skórczyńska, op. cit., s. 56.

43 Diagnoza zaburzeń..., s. 25.
} 
żonej ostrości słuchu ${ }^{44}$. Analizy nagrań wideo wykazują, że już w pierwszych 12 miesiącach życia niemowlęta, które otrzymały diagnozę autyzmu, demonstrowały deficyty $\mathrm{w}$ komunikowaniu się. Większość rodziców podaje jako pierwszą przyczynę swojego niepokoju brak lub opóźniony rozwój mowy. W badaniach prowadzonych przez Elaine Coonrod i Wendy L. Stone w grupie rodziców (44 osoby) dzieci w wieku 24-36 miesięcy, w tym 22 dzieci z diagnozą autyzmu i 22 dzieci z diagnozą opóźnienia rozwoju (Developmental Delay $\mathrm{DD}$ ) ten problem był podawany z skali $72-98 \%$. W innych badaniach tych samych autorów opóźniony rozwój mowy był powodem obaw 91\% rodziców dzieci z autyzmem i 77 \% rodziców dzieci z opóźnieniem rozwoju. Niepokój rodziców budzą także wyraźne spowolnienie tempa rozwoju (np. po okresie gaworzenia nie pojawiają się pierwsze słowa) lub utrata uprzednio nabytych przez dziecko umiejętności. W 20-35 \% przypadków zgłaszany jest regres, który obejmuje utratę słów, wokalizacji czy niewerbalnych umiejętności komunikowania się (np. za pomocą gestów lub kontaktu wzrokowego) ${ }^{45}$.

Już w 1. roku życia można zaobserwować szczególne trudności w prewerbalnej komunikacji. Z badań prowadzonych przez Chrisa P. Johansona i Scotta M. Myersa z 2007 r. wynika, że są to: brak naprzemiennej wokalizacji między niemowlęciem a rodzicem, brak reakcji na głos matki, ojca lub innego bliskiego opiekuna, brak ekspresji wokalno-emocjonalnej w rodzaju "ooo", „uu”, opóźniony repertuar gaworzenia (po 9. miesiącu życia lub jego brak do 12. miesiąca życia), zubożona wokalizacja, zaburzona prozodia języka, znikomy lub nieobecny repertuar gestów (np. machania "papa", wskazywania palcem), brak spojrzenia kierowanego do innych osób, brak koordynacji pomiędzy spojrzeniem, mimiką, gestykulacją i wydawanymi dźwiękami ${ }^{46}$.

${ }^{44}$ M. Skórczyńskka, Autyzm a opóźnienie rozwoju, [w:] Dzieci z zaburzeniami taczonymi. Trudne ścieżki rozwoju, red. B. Winczura, Oficyna Wydawnicza „Impuls”, Kraków 2012, s. 15.

${ }^{45}$ M. Skórczyńska, Autyzm a opóźnienie..., s. 23.

${ }^{46}$ M. Skórczyńska, Wczesne diagnozowanie..., s. 48; E. Pisula, Wspomaganie osób..., op. cit., s. 449. 
Z uwagi na ograniczoną funkcję komunikacyjną, dzieci z wczesnym rozwojem autyzmu $\mathrm{w}$ fazie prewerbalnej stosują nietypowe sposoby porozumiewania się. Nie wykazują zainteresowania słowem mówionym, ani też żadnym dźwiękiem, sprawiają wrażenie, jakby miały problemy ze słuchem. Płacz niemowlaka z grupy ryzyka autyzmu wydaje się być pozbawiony ekspresji. Gaworzenie nie występuje w ogóle lub pojawia się znacznie później, jest mniej urozmaicone, pozbawione ekspresji, bez modulacji o charakterze konwersacyjnym.. Nie używają swojego głosu w celu zwrócenia na siebie uwagi. Znaczna grupa dzieci nie mówi w ogóle, a u tych, które posługują się mową, jej rozwój jest zazwyczaj nie tylko opóźniony, ale i zaburzony ${ }^{47}$. Według Pauline A. Filipek i in. (w publikacjach z 1999 i 2000 r.) za oznaki opóźnień w rozwoju mowy u dzieci z grupy ryzyka autyzmu przyjmuje się:

- brak wypowiadania przez dziecko słów ze zrozumieniem po 1. roku życia,

- brak budowania prostych zdań po 2. roku życia (brak zdań dwuwyrazowych wypowiadanych spontanicznie po 24 . miesiącu życia),

- brak rozwoju mowy, która służy porozumiewaniu się z innymi,

- regres w zakresie rozwoju mowy lub umiejętności społecznych w każdym wieku ${ }^{48}$.

Małe dzieci z podejrzeniem autyzmu komunikują się głównie lub wyłącznie w celu regulowania zachowań innych osób kiedy chcą o coś poprosić lub coś odrzucić. Brak jest komunikowania skierowanego na zwrócenie czyjejś uwagi na przedmiot, zjawisko lub osobę. Deficyt ten stanowi charakterystyczną cechę dla autyzmu i nie jest symptomatyczny dla dzieci z opóźnieniami rozwoju. Dzieci w tej grupie zaburzeń mają trudności w nabywaniu konwencjonalnych i symbolicznych aspektów komunikowania się ${ }^{49}$.

Ponadto w ogóle lub rzadko używają intencjonalnie gestów lub wokalizacji po to, by przekazać komuś informację i mają problemy

\footnotetext{
47 H. Jaklewicz, op. cit., s. 119.

48 M. Skórczyńska M., Wczesne diagnozowanie..., s. 41.

49 Skórczyńska M., Autyzm a opóźnienie..., s. 24.
} 
z przekazywaniem komunikatów za pomocą spojrzenia. Nie próbują wyrazić mimiką swoich emocji, nie potakują głową, gdy się z czymś zgadzają ani nie uśmiechają się, by wspomóc komunikację społeczną. Nie odpowiadają także na takie sygnały kierowane do nich. Radząc sobie z brakiem umiejętności potrzebnych do zaspokojenia potrzeb, posługują się czasami ciałem innej osoby (najczęściej ręką) jak przedmiotem, np. prowadzą rękę do upragnionego obiektu, popychając jej rękę w danym kierunku. Niekiedy rolę komunikatu odgrywają zachowania agresywne, krzyk albo płacz ${ }^{50}$.

Większość małych dzieci z autyzmem sprawia wrażenie, jakby nie rozumiała, co się do nich mówi. Obserwuje się dysproporcje pomiędzy gotowością do powtarzania słów, nazywania obiektów a zdolnością rozumienia. Według relacji rodziców około $25 \%$ dzieci w wieku 12 lub 18 miesięcy wypowiada pojedyncze słowa. Pierwsze oznaki rozumienia słów u połowy dzieci $z$ autyzmem nie pojawiają się przed osiągnięciem przez nie wieku umysłowego 2 lat i 6 miesięcy. Zdolność rozumienia słów na poziomie charakterystycznym dla dziecka 16-miesięcznego dzieci z autyzmem osiągają dopiero w wieku umysłowym 4 lat. W samym wypowiadaniu słów różnica jest mniejsza, opóźnienie mieści się w przedziale od 8 do 19 miesięcy ${ }^{51}$. Tony Charman i in., prowadząc badania nad reakcją małych dzieci z autyzmem na trzy typy komunikatów: własne imię, zakaz („nie”) oraz zdanie oznajmujące (,tu jest mama/tata"), wykazali, że zaledwie połowa dzieci z autyzmem w wieku poniżej 2 lat reagowała na własne imię, 70\% odpowiadało prawidłowo na zakaz „nie”, zaś 30\% rozumiało komunikat „tu jest mama/tata”. Tylko 30\% 2-letnich dzieci naśladowało słowa, a 15\% potrafiło nazwać przedmioty. Dopiero $\mathrm{w}$ wieku 4 lat niemal wszystkie badane dzieci z autyzmem reagowały na swoje imię i rozumiały znaczenie słowa „nie”. Nieco ponad 80\% dzieci powtarzało słowa, ale nadal tylko 52\% nazywało obiekty ${ }^{52}$.

50 E. Pisula, Autyzm. Przyczyny..., s. 43-44.

51 E. Pisula, Małe dziecko..., s. 36.

52 E. Pisula, Zaburzenia komunikacji u dzieci z autyzmem, [w:] Kiedy mózg pracuje inaczej... - postrzeganie, ruch, emocje, komunikacja, "Zeszyty Naukowe” 6 na Międzynarodowej Konferencji org. Przez Ogólnopolską Fundację na rzecz Dzieci Niepełnosprawnych „Promyk Słońca”, Wrocław, 5 grudnia 2008, s. 43. 
Generalnie rozumienie mowy $\mathrm{u}$ dzieci $\mathrm{z}$ autyzmem jest znacznie opóźnione. W późniejszym okresie może być ono upośledzone $\mathrm{w}$ różnym stopniu, począwszy od zupełnego braku rozumienia mowy, poprzez rozumienie instrukcji w określonym kontekście lub mowy popartej gestem, aż do dyskretnych zaburzeń dotyczących rozumienia znaczeń abstrakcyjnych, przenośni, żartów ${ }^{53}$.

Około 25-30\% dzieci z ASD zaczyna wypowiadać pierwsze słowa około 1. roku życia, ale często między 15. a 24. miesiącem życia przestaje mówić, a ich ekspresja słowna sprowadza się do kilku komunikatów, głównie takich, które mają na celu zaspokojenie aktualnej potrzeby. Regres może obejmować także utratę umiejętności komunikowania się za pomocą gestów (machanie, wskazywanie itp.) lub umiejętności komunikacji społecznej (kontakt wzrokowy, reakcje na pochwałę). Regres może być stopniowy lub nagły, może nakładać się na subtelne, istniejące wcześniej opóźnienia rozwojowe lub atypowy przebieg rozwoju (np. niezwykłe intensywne zainteresowanie w 1 . roku życia niektórymi przedmiotami lub innymi bodźcami, które nie mają społecznego charakteru). Regres w rozwoju mowy związany jest z wycofywaniem się dziecka z kontaktów społecznych oraz obroną przed zmianami, sztywnością w zachowaniu, zaburzeniami snu albo problemami z jedzeniem ${ }^{54}$.

U około $3 / 4$ dzieci z autyzmem, które posługują się mową, można zaobserwować tzw. echolalię55. Mowa taka nie zawiera intencji komunikacyjnych i polega na powtarzaniu natychmiastowym lub odroczonym słów, pierwszych lub ostatnich jego sylab bądź zdań wypowiedzianych przez kogoś innego. Czasami dziecko odtwarza skierowane do niego lub zasłyszane zdanie w formie gramatycznej i tonacji, w jakiej zostało sformułowane, np. „czy chcesz cukierka?”. Wypowiedzi echolaliczne są odtwarzane przez dziecko z dokładną intonacją i melodią, w jakiej zostały wygłoszone. Są one oderwane

${ }^{53}$ G. Jagielska, op. cit., s. 39.

54 M. Skórczyńska, Wczesne diagnozowanie..., s. 48-49.

55 J. Błeszyński, Czy echolalia w autyzmie jest problemem komunikacyjnym?, [w:] Autyzm. Na granicy zrozumienia, red. B. Winczura, Oficyna Wydawnicza "Impuls”, Kraków 2009, s. 106. 
od sytuacji i nie mieszczą się w kontekście toczącej się wokół dziecka rozmowy ${ }^{56}$. U dziecka $\mathrm{z}$ autyzmem echolalia może pozostać głównym sposobem wypowiadania się i utrzymywać się przez całe życie. Oznacza to, że dziecko nie potrafi samodzielnie zbudować komunikatu, a tego typu wypowiedzi można odczytać jako prośbę, protest lub potwierdzenie czegoś. Interpretacja tego typu komunikatów nie jest zatem łatwa i wymaga dobrej znajomości dziecka. W mowie dzieci z autyzmem często występują stereotypie językowe. Dziecko wielokrotnie powtarza niektóre słowa, frazy, teksty reklam, fragmenty filmów, szczególnie bajek lub programów telewizyjnych. Takie wypowiedzi dziecka zazwyczaj nie służą komunikowaniu się i ich funkcje są zbliżone do innych zachowań stereotypowych. Odmienność rozwoju mowy dotyczy także nietypowej intonacji, tempa, rytmu wypowiedzi oraz ograniczonego i nierównomiernego zasobu słownictwa. Ponadto charakterystyczne są trudności z używaniem zaimków osobowych. Mówią o sobie "ty" albo „on”, mylą też zaimki określające inne osoby. Takie błędy mogą pojawiać się w rozwoju mowy u dzieci zdrowych, ale u dzieci $\mathrm{z}$ autyzmem wykraczają poza typowe ramy rozwojowe i czasowe ${ }^{57}$. Niektóre dzieci z autyzmem mają problem z włączeniem określeń do mowy funkcjonalnej. Na przykład mają opanowane pamięciowo nazwy kolorów, kształtów, liczb czy liter, ale nie potrafią ich wskazywać, kiedy są pytane o nie w inny niż zazwyczaj sposób. Opanowują język w sposób schematyczny i sztywny. Ucząc się znaczenia słów, wiążą je z konkretnymi obiektami, na przykład „Pan” może zostać skojarzony z konkretnym mężczyzną, a „kot” z określonym kotem $^{58}$.

Poziom rozwoju mowy i umiejętności komunikacyjne są jednym z prognostyków dalszego przebiegu rozwoju dziecka. Im wcześniej i im lepiej rozwija się mowa, tym lepsze są prognozy rozwojowe. W niewielkiej grupie dzieci, gdzie obserwuje się łagodne opóźnie-

56 H. Jaklewicz, op. cit., s. 119-120.

57 E. Pisula, Autyzm. Przyczyny..., s. 52.

${ }^{58}$ M. Skórczyńska, Wczesne diagnozowanie..., s. 48. 
nia/zaburzenia mowy autyzm może pozostawać nierozpoznawalnym aż do wieku przedszkolnego, kiedy to dopiero widoczne stają się trudności w nawiązywaniu relacji społecznych z rówieśnikami ${ }^{59}$.

\section{Stereotypowe, powtarzające się wzorce zachowania}

Dzieci ze spektrum autyzmu mogą demonstrować atypowe zachowania $\mathrm{w}$ różnych sferach, np. dziwne manieryzmy, niezwykłe przywiązanie do przedmiotów, obsesje, kompulsje czy stereotypie. Około 5\% rodziców wyraża niepokój z powodu stereotypowych zachowań swoich dzieci. Chociaż wcześnie dostrzegają ową nietypowość zachowania dziecka, to jednak wielu z nich nie potrafi dokładnie sprecyzować ich charakteru i przyczyn. Najczęściej wymieniają je w kontekście napadów złego humoru, nadruchliwości, braku współdziałania, niebawienia się zabawkami, nadwrażliwości na niektóre bodźce ${ }^{60}$. Rodzice podają, że ich dzieci często powtarzają nieustannie te same ruchy. Najczęściej są to: trzepotanie rękami, specyficzne poruszanie dłońmi czy palcami (pstrykanie palcami, klaskanie w dłonie), kołysanie się, kiwanie się, wyrzucanie w górę ramion, kręcenie się wokół własnej osi, chodzenie w kółko, uderzanie głową, wachlowanie dłońmi przy twarzy. Choć czynności te stanowią formę autostymulacji, to niekoniecznie zawsze muszą być dla nich źródłem samej przyjemności, wręcz przeciwnie. $Z$ relacji rodziców wynika, że pewna grupa dzieci wykonując te czynności, często okazuje niepokój, płacz, krzyk. W niektórych przypadkach ruchy stereotypowe mogą być rekcją na stres $\mathrm{w}$ kontakcie ze środowiskiem, w którym rozwija się na co dzień dziecko ${ }^{61}$.

Większość stereotypii ruchowych jest jednak na tyle uciążliwa, że utrudnia i uniemożliwia wykonywanie codziennych zadań oraz uczenie się nowych umiejętności. Stereotypie, choć są wysoce cha-

\footnotetext{
59 E. Pisula, Autyzm. Przyczyny..., s. 53.

60 E. Pisula, Mate dziecko z autyzmem..., s. 61-62.

61 P. Randall, J. Parker, op. cit., s. 61.
} 
rakterystyczne dla małych dzieci z grupy ryzyka autyzmu, nie są jednak ich cechą specyficzną, gdyż występują także $\mathrm{u}$ dzieci z upośledzeniem umysłowym $\mathrm{i} / \mathrm{lub} \mathrm{z}$ poważnymi zaburzeniami sensorycznymi. Nawet małe dzieci o prawidłowym rozwoju, szczególnie przed opanowaniem umiejętności płynnego wypowiadania się, mogą przelotnie trzepotać rękami w momentach podekscytowania lub przeżywanej frustracji. Zachowania stereotypowe związane z ASD w wczesnych latach życia dziecka, pojawiają się jako zwiastuny tych zachowań. Do ukończenia 12. miesiąca życia stereotypie ruchowe współistnieją z ogólnym niepokojem i koncentrują się głównie na ruchach dłoni i głowy. Aktywność tych dzieci polega najczęściej na powtarzających się rytmicznych ruchach, np. skrobaniu kołderki lub łóżeczka, postukiwaniu w przedmiot, bujaniu się, a nawet uderzaniu główką o twarde obicia62. Po 12. miesiącu życia zachowania stereotypowe nasilają się, gdy zostanie naruszone otoczenie lub zmienia się schemat postępowania. Zachowania te obejmują głównie podskoki i kręcenie się wokół własnej osi, ale także ostukiwanie i wprawianie przedmiotów w ruch wirowy. Pojawia się silny lęk w sytuacjach zmieniających dotychczasowe stereotypy postępowania. Zabawa stereotypowa, samotna ma głównie charakter przyjemności. Dziecko najczęściej bawi się zabawkami mechanicznymi, którymi może kręcić, stukać63. Zwykle powtarza te same czynności, układa w szeregi klocki, samochody lub inne zabawki albo tylko ich fragmenty. Obserwuje się brak aktywności spontanicznej. Wykazano, że trudności z regulacją własnej aktywności są $\mathrm{u}$ dzieci z autyzmem szczególnie wyraźne podczas zabawy swobodnej.

Około 2. roku życia zachowania stereotypowe stają się już bardziej wyraziste, zdecydowanie poszerza się ich repertuar. Centralne miejsce w zachowaniu dziecka zajmują: poruszanie dłońmi, palcami (machanie, wachlowanie, trzepotanie) w peryferycznych obszarach pola widzenia, uporczywe wpatrywanie się w jakiś obiekt absorbu-

62 M. Skórczyńska, Wczesne diagnozowanie..., s. 50.

63 J. Błeszyński, op. cit., s. 97. 
jący uwagę, chodzenie na palcach i/lub utrzymujące się w czasie wąchanie czy lizanie przedmiotów niejadalnych. Preferują zamiast miękkich pluszowych zabawek twarde przedmioty, jak: długopisy, latarki, klucze, figurki, sznurki, elementy zabawek, np. kółka od samochodu, nogi od lalki. Nalegają na trzymanie tych przedmiotów przez cały czas, chociaż są one rzadko wykorzystywane przez nich do zabaw. Nasilają się zachowania lękowe i rekcje o silnej ekspresji. $\mathrm{W}$ badaniach longitudinalnych dzieci $\mathrm{z}$ grupy ryzyka Catherine Lord odkryła, że u ponad $87 \%$ dzieci zdiagnozowanych w wieku 3 lat jako autystyczne, rodzice relacjonowali występowanie manieryzmów w zakresie ruchów rąk i dłoni oraz specyficznych zainteresowań sensorycznych $w$ wieku 2 lat ${ }^{64}$. Autorka zaznacza, że tego typu zachowania są jednak łatwiejsze do odróżnienia w przypadku dzieci 3-letnich niż 2-letnich z diagnozą autyzmu. Rodzice dzieci starszych zauważają te deficyty częściej niż rodzice dzieci młodszych. Nie wiadomo, czy dzieje się tak dlatego, że dzieci nie mogą im sprostać, czy też zaburzenia autystyczne nasilają się znaczniej między 2. a 3. rokiem życia65.

U dzieci autystycznych można zaobserwować graniczącą nawet z obsesją fascynację poszczególnymi przedmiotami i wykorzystywanie ich w sposób niezgodny z przeznaczeniem.

Jeśli przedmioty te zostaną umyślnie usunięte lub zagubią się, dzieci mogą wykazywać głęboki niepokój, a nawet napady wściekłości. Czasem obsesyjne zainteresowania dotyczą tras autobusowych, rozkładów jazdy pociągów, liczb lub figur. Ponad 60\% dzieci wykazuje przywiązanie do codziennej rutyny i odmawia jakichkolwiek zmian $\mathrm{w}$ znanych im rytuałach $\mathrm{w}$ najbliższym środowisku. Dotyczy to np. czynności związanych z kładzeniem się spać, odwiedzaniem sklepów zawsze $w$ tej samej kolejności, podążaniem $\mathrm{w}$ pewne miejsca zawsze tą samą trasą czy picie z określonego kubka. Nalegają na stały plan dnia. W zachowaniu widoczny jest brak elastyczności. Przy próbach wprowadzenia jakichkolwiek zmian,

\footnotetext{
${ }^{64}$ M. Skórczyńska, Wczesne diagnozowanie..., s. 50-58.

65 E. Pisula, Autyzm u dzieci..., s. 54.
} 
wręcz minimalnych, niedostrzegalnych dla innych ludzi, dzieci gwałtownie reagują, wykazując niepokój, krzyk, płacz ${ }^{66}$. Protesty dziecka mogą szybko przybrać postać zachowań agresywnych. Należą do nich uderzanie głową, gryzienie rąk, wkładanie palców do uszu i oczu, drapanie ciała itp. Zachowania te mogą prowadzić do poważnych uszkodzeń. Między innymi mogą być wywołane przez frustrację spowodowaną nieskutecznymi próbami porozumiewania się, przeżywanego niepokoju w nowym nieznanym dziecku otoczeniu, albo z powodu znudzenia, zmęczenia, braku snu, głodu czy bólu67.

Sztywne, stereotypowe zachowania u dzieci z spektrum autyzmu mogą się zmieniać wraz z rozwojem dziecka i mogą przyjmować różne formy. Ograniczony repertuar zachowań pozostaje w związku z poziomem rozwoju umysłowego dziecka. Dzieci o niższym poziomie rozwoju częściej wąchają, liżą i dotykają przedmioty, a dzieci o wyższym poziomie rozwoju intelektualnego częściej powtarzają złożone czynności i preferują inne formy aktywności. Są także dane wskazujące, że stereotypowe zachowania są znacznie częstsze $u$ małych dzieci $z$ autyzmem niż $u$ ich rówieśników z innymi zaburzeniami w rozwoju i zachowaniu lub u dzieci z grupy ryzyka, ale bez diagnozy autyzmu. Wszelkie atypowe zachowania dziecka są bardzo kłopotliwe i męczące dla otoczenia. Powodują trudności wychowawcze i zwiększają poziom stresu w rodzinie dziecka. Stanowią także zewnętrzny, łatwo dostrzegalny przejaw atypowego rozwoju i mają w związku $\mathrm{z}$ tym znaczenie stygmatyzujące. Częstym określeniem na takie zachowania dziecka jest „dziwaczność”. Analiza ograniczonych schematów zachowania u małych dzieci w wieku poniżej 2 lat wykazała, że ich obecność może być wysoce przydatna $\mathrm{w}$ rozpoznawaniu autyzmu68. Powtarzające się i stereotypowe wzorce zachowań oraz ograniczony i schematyczny repertuar zachowania są traktowane jako jedna z osiowych cech ASD.

\footnotetext{
66 P. Randall, J. Parker, op. cit., s. 101-102.

${ }^{67}$ M. Skórczyńska, Wczesne diagnozowanie..., s. 51.

68 E. Pisula, Autyzm. Przyczyny..., s. 56-57.
} 
$\mathrm{W}$ opisach zachowania małych dzieci z podejrzeniem autyzmu uderza także fakt, że ich ogólny poziom aktywności odbiega zazwyczaj od tego, co możemy zaobserwować u innych dzieci. Czasami dominuje u dziecka niemal całkowita bierność. Wydaje się całkowicie wyobcowane, charakterystyczny jest brak ciekawości, zainteresowania otoczeniem, zarówno fizycznym, jak i społecznym. Wielokrotnie rodzice podają, że dziecko posadzone w jakimś miejscu pozostaje tam, nie podejmując próby przemieszczania, zabawy ani też podążania za oddalającym się opiekunem. Drugim, znacznie odmiennym obrazem aktywności u dziecka może być wysoka nadaktywność, nadruchliwość, połączona z niezdolnością do skupienia uwagi na kimś lub czymś choćby na chwilę. Dziecko jest w nieustannym ruchu, biega, skacze, wspina się na meble. Jego aktywność sprawia wrażenie chaotycznej, pozbawionej celu i bez przerwy się zmienia. Towarzyszy jej wysoki poziom pobudzenia, regulowany za pomocą ekspresji ruchowej, ale zarazem aktywność ta służy autostymulacji. Często towarzyszą temu napady złości i agresji, krzyk w miejscach publicznych, reakcje lękowe i paniczne. Taki wzorzec zachowania dziecka mylony jest często z zespołem nadpobudliwości ruchowej z deficytem uwagi (ADHD). Należy jednak zaznaczyć, że u niewielkiej grupy dzieci możliwe jest współwystępowanie tych zaburzeń 69 .

U dzieci z autyzmem mogą występować symptomy świadczące o zaburzeniach integracji sensorycznej. Nie różnicują one jednak dzieci z ASD od dzieci z innymi zaburzeniami rozwojowymi ${ }^{70}$. Charakterystyczną cechą dysfunkcji integracji sensorycznej są niewłaściwe odpowiedzi na dopływające bodźce sensoryczne. Do typowych objawów dezintegracji sensorycznej $\mathrm{u}$ małych dzieci $\mathrm{z}$ autyzmem należą m.in.: nadwrażliwość lub niedowrażliwość na dotyk, światło, dźwięk, ruch, smak i zapachy (np. czynniki sensoryczne związane z jedzeniem: kolor, konsystencja, smak mogą pro-

${ }^{69}$ E. Pisula, Małe dziecko z autyzmem..., s. 53.

${ }^{70}$ M.L. Kutscher, J. Glick, Zaburzenia integracji sensorycznej, [w:] Dzieci z zaburzeniami łaczonymi, red. L.M. Kutscher, T. Attwood, R.R. Wolff, Wydawnictwo K.E.LIBER, Warszawa 2007, 168-169. 
wadzić u dziecka do wysoce restrykcyjnej diety); zaburzenia koncentracji, niezwykle niski lub wysoki poziom aktywności, częste wyłączanie się lub wycofywanie, nieradzenie sobie $\mathrm{z}$ frustracją, $\mathrm{z}$ uspakajaniem się, intensywne, nieproporcjonalne reakcje na zmiany sytuacji i nieznane miejsca, impulsywność, trudności w przechodzeniu z jednej aktywności do drugiej ${ }^{71}$.

$\mathrm{W}$ ostatnich latach pojawia się coraz więcej informacji na temat wczesnych zaburzeń rozwoju ruchowego dziecka jako wskaźnika zagrożenia autyzmem. Deficyty tego rodzaju dotyczą dużej i małej motoryki, zachowania równowagi, tempa ruchów, utrzymania postawy ciała oraz motoryki aparatu oralnego. Badania aktywności ruchowej dzieci z grupy ryzyka autyzmu prowadzone przez Osnata i Philipa Teitelbaumów wykazały, że w rozwoju tym obecne są wyraźne nieprawidłowości, polegające głównie na asymetrii ruchów ciała. Badacze uważają, że rozpoznanie zwiastunów tych zaburzeń u dziecka w wieku od 6. do 8. miesiąca życia jest w pełni możliwa. Wykazali, że u tych dzieci, u których zdiagnozowano zaburzenia ze spektrum autyzmu, już w pierwszych miesiącach życia można zaobserwować asymetrię ruchów podczas leżenia i pełzania, utrzymywanie się poza właściwym okresem rozwojowym asymetrycznego tonicznego odruchu szyjnego oraz brak odruchów obronnych podczas utraty równowagi. Dodatkowo u dzieci tych odwracanie się $\mathrm{z}$ pleców na brzuch, raczkowanie, siadanie i chodzenie nie rozwijają się we właściwym czasie ${ }^{72}$. Zaburzenia ruchowe mogą stanowić jeden $\mathrm{z}$ najwcześniejszych sygnałów nieprawidłowego rozwoju dziecka $\mathrm{z}$ autyzmem, jeszcze przed pojawieniem się widocznych deficytów społecznych lub komunikacyjnych. Należy jednak podkreślić, że pomimo wieloletnich badań $w$ tej dziedzinie, nie udało się ustalić typowego dla autyzmu wzorca zaburzeń motorycznych, a także, że nie u wszystkich dzieci z grupy ryzyka autyzmu można zaobserwować owe odchylenia od normy rozwojowej73.

71 M. Skórczyńska, Wczesne diagnozowanie..., s. 52-53.

72 O. Teitelbaum, P. Teitelbaum, Czy twoje dziecko ma autyzm? Jak rozpoznawać najwcześniejsze oznaki autyzmu, Wydawnictwo Harmonia Universalis, Gdańsk 2012.

73 E. Pisula, Od badań mózgu..., s. 43-45. 
Zaburzenia snu i łaknienia, agresja i autoagresja, problemy z czynnościami fizjologicznymi, wysoka labilność emocjonalna (napady złości, krzyku, płaczu bez łez) są objawami, które często towarzyszą rozwojowi zaburzeń ze spektrum autyzmu u małych dzieci $^{74}$.

\section{Wczesne wykrywanie zaburzeń ze spektrum autyzmu}

Rozpoznawanie symptomów autyzmu przed 2. rokiem życia dziecka pozostaje zadaniem niezwykle trudnym. Większość klinicystów podaje, że obraz zachowania dziecka przed ukończeniem 2. roku życia może nie być wystarczająco jasny, by móc sformułować diagnozę autyzmu. $U$ tak małego dziecka nie zawsze ujawniają się $\mathrm{w}$ pełni objawy przyjęte przez obowiązujące kryteria diagnostyczne. Ponadto zaburzenia należące do autystycznego spektrum zaburzeń charakteryzują się znaczną dynamiką rozwoju. Rozwój tych dzieci jest bardzo zróżnicowany, nie tylko pod względem tempa, ale także kolejności pojawienia się poszczególnych faz rozwoju. Dotyczy to zdolności poznawczych, głębokości deficytów społecznych, umiejętności porozumiewania się, a także innych problemów towarzyszących objawom osiowym. Ponadto niektóre zachowania różniące małe dzieci autystyczne od ich prawidłowo rozwijających się rówieśników są związane prawdopodobnie $\mathrm{z}$ upośledzeniem umysłowym lub zaburzeniami mowy. Jeżeli dziecko jest upośledzone umysłowo, symptomy autyzmu mogą zostać złożone na konto upośledzenia. Dlatego też różnicowanie dzieci autystycznych z upośledzeniem umysłowym od dzieci o takim samym stopniu upośledzenia, ale bez autyzmu jest trudniejsze niż odróżnianie ich od dzieci w normie intelektualnej ${ }^{75}$.

Jak do tej pory nie udało się ustalić algorytmów służących do diagnozy ASD u dzieci poniżej 1. roku życia, które oparte są na

74 H. Jaklewicz, op. cit., s. 118; G. Jagielska, Objawy autyzmu..., s. 48-49.

75 E. Pisula, Autyzm u dzieci..., s. 53. 
empirycznych dowodach ${ }^{76}$. Zgodnie z aktualnym stanem wiedzy, najwcześniejszym momentem, kiedy możemy rozpoznać autyzm, jest 18. miesiąc życia. Wskazują na to analizy zapisów pochodzących z kontrolnych badań prowadzonych przez pediatrów (różniących się wyraźnie od wyników badań dzieci 12-miesięcznych), a także wyniki prowadzonych $\mathrm{w}$ tym obszarze badań. $\mathrm{W}$ praktyce klinicznej dysponujemy różnymi narzędziami diagnostycznymi do badań przesiewowych. Najczęściej narzędzia te są przydatne do stosowania w ogólnej populacji dzieci objętych podstawową opieką zdrowotną. Mogą być pomocne w wykrywaniu ASD u bardzo małych dzieci, nie pozwalają natomiast na różnicowanie ASD od innych zaburzeń rozwojowych. Ponadto nie wszystkie z dostępnych narzędzi diagnostycznych pomagają wyłapać ryzyko autyzmu u bardzo małych dzieci poniżej 18. miesiąca życia ${ }^{77}$.

Za najprzydatniejsze narzędzia do wczesnego przesiewowego wykrywania ASD u małych dzieci uznaje się m.in. Kwestionariusz Autyzmu w Okresie Poniemowlęcym - Checklist for Autism in Toddlers - CHAT (od 18. miesiąca życia) opracowany przez Simona Baron-Cohena, Jane Allen, Christophera Gillberga ${ }^{78}$ i jego zmodyfikowaną wersję Modified Checklist for Autism in Toddlers M-CHAT (od 24. do 30. miesiąca życia). Gillian Baird i in. ${ }^{79}$, prowadząc przez wiele lat badania kontrolne nad wprowadzeniem CHAT-a do badań przesiewowych ogólnej populacji, wykryli jego wysoką użyteczność (większość dzieci, które nie zaliczyło pozytywnie CHAT-a, nie otrzymały później diagnozy autyzmu) i pozytywną wartość prognostyczną (większość dzieci, które nie zaliczyły CHAT-a była później diagnozowana jako autystyczna). W trakcie

76 A. Steiner, T.R. Goldsmith, A.V. Snow, K. Chawarska, op. cit., s. 1185.

77 M. Skórczyńska, Wczesne diagnozowanie autyzmu..., s. 41.

78 S. Baron-Cohen, J. Allen, Ch. Gillberg, Can autism be detected at 18 months? The needle, the haystack, and the CHAT, "Brithish Journal of Psychiatry" 1992, 161, s. $839-843$.

${ }^{79} \mathrm{G}$. Baird, T. Charman, S. Baron-Cohen, A screening instrument for autism at 18 months of age: A 6 year follow - up study, "Journal of the American Academy of Child and Adolescent Psychiatry" 2000, 39, s. 694-702. 
prowadzonych badań okazało się jednak, że jest to narzędzie mniej czułe na łagodniejsze symptomy autyzmu, gdyż dzieci diagnozowane później jako AS bądź z autyzmem atypowym nie zostały wychwycone w wieku 18 miesięcy w badaniach z użyciem CHAT-a. Chcąc zwiększyć czułość diagnostyczną narzędzia, w 1999 r. Diana L. Robins, Deborah Fein, Marianne L. Barton, James A. Green ${ }^{80}$ dokonali w nim zmian i zaproponowali jego zmodyfikowaną wersję M-CHAT, gdzie wykluczyli obserwację prowadzoną przez lekarza, a rozszerzyli ilość pytań kierowanych do rodziców. Tym samym podnieśli jego użyteczność praktyczną w badaniach przesiewowych dzieci 24-misięcznych. Inne, przydatne narzędzie przesiewowe dla dzieci w wieku 24-36 miesięcy to interaktywne narzędzie skriningowe - Screening Tool for Autism in Two-Yers-Olds - STAT ${ }^{81}$. Kryteria diagnostyczne ujęte $\mathrm{w}$ tym narzędziu są ściśle powiązane z późniejszym rozpoznaniem ASD. Są to brak lub ograniczona częstość reagowania na imię, podążania za wskazywaniem lub spojrzeniem, wskazywania z powodów innych niż proszenie oraz podejmowania zabawy opartej na udawaniu. Test ten został stworzony na podstawie dowodów empirycznych pokazujących, że zaburzenia ze spektrum autyzmu można zdiagnozować w wieku 2 lat, ponieważ dzieci te prezentują specyficzne deficyty dotyczące kompetencji społecznych w sferze naśladowania, zabawy funkcjonalnej i kierowania uwagi. Na podstawie klinicznych i naukowych obserwacji wybrane zostały aktywności, które najlepiej różnicują grupę dzieci $\mathrm{z}$ autyzmem od grupy kontrolnej ${ }^{82}$.

${ }^{80}$ D.L. Robins, D. Fein, M.L. Barton, J.A. Green, The Modified - Checklist for Autism in Toddlers: An initial study investigating the early detection of autism and pervasive developmental disorders. "Journal of Autism and Developmental Disorders" 2001, 31(2), s. 131-144.

81 W.L. Stone, E.B. Lee, L. Ashford i wsp., Can autism be diagnosed accurately in children under 3 years? "Journal of Child Psychology and Psychiatry" 1999, 40(2), s. 219-226; W.L. Stone, E.E. Coonrod, O.Y. Ousley, Brief report: Screening tool for autism in 2-year-olds (STAT): Development and preliminary data,. „Journal of Autism and Developmental Disorders" 2000, 30(6), s. 607-612.

82 A. Rynkiewicz, M. Kulik, op. cit., s. 43-44. 
Ze względu na złożony i specyficzny obraz przebiegu procesów rozwojowych i ich wzajemnych powiązań w populacji dzieci z zaburzeniami spektrum autyzmu wymagane jest, by proces diagnozowania, czy też model wczesnego wykrywania autyzmu, był prowadzony wieloetapowo. Badania kliniczne pokazały, że tylko systematyczna obserwacja dziecka, przy zastosowaniu odpowiednich narzędzi diagnostycznych (nawet wielokrotne ich użycie w odpowiednim czasie) dają podstawę do stawiania ostatecznej diagnozy $^{83}$. To priorytetowy aspekt diagnostyczny, warunkujący wczesne rozpoczęcie terapii, a tym samym dający perspektywę na zmniejszenie trudności dziecka oraz zapobieganie zaburzeniom, które mogą pojawić się jako tak zwane zaburzenia wtórne. Dysponujemy coraz większą liczbą danych wskazujących na to, że wczesna interwencja $\mathrm{w}$ odniesieniu do dzieci ze spektrum autyzmu przynosi pozytywne wyniki ${ }^{84}$.

\section{Bibliografia}

Baird G., Charman T., Baron-Cohen S., A screening instrument for autism at 18 months of age: A 6- year follow - up study, "Journal of the American Academy of Child and Adolescent Psychiatry" 2000, 39.

Ball J., Autyzm a wczesna interwencja. Rzeczowe pytania, życiowe odpowiedzi, Wydawnictwo Harmonia Universalis, Gdańsk 2016.

Baranek G.T., Autism during infancy: a retrospective video analysis of sensory - motor and social behaviors at 9-12 moths of age, "Journal of Autism and Developmental Disorders" 1999, vol. 29, no. 3 .

Baron-Cohen S., Allen J., Gillberg Ch., Can autism be detected at 18 months? The needle, the haystack, and the CHAT, "Brithish Journal of Psychiatry" 1992, 161.

Blok B., Brzeska Z., Ignaczewska B., Diagnoza i wspomaganie rozwoju dziecka z autyzmem w Specjalnym Ośrodku Rewalidacyjno - Wychowawczym dla Dzieci i młodzieży z Autyzmem, [w:] Wczesne wspomaganie rozwoju dziecka od chwili wykrycia niepetnosprawności do podjęcia nauki w szkole, red. T. Serafin, Ministerstwo Edukacji Narodowej i Sportu, Warszawa 2005.

${ }^{83}$ M. Skórczyńska, Wczesne diagnozowanie..., s. 52.

$84 \mathrm{~J}$. Ball, Autyzm a wczesna interwencja. Rzeczowe pytania, życiowe odpowiedzi. Wydawnictwo Harmonia Universalis, Gdańsk 2016. 
Błeszyński J., Czy echolalia w autyzmie jest problemem komunikacyjnym?, [w:] Autyzm. Na granicy zrozumienia, red. B. Winczura, Oficyna Wydawnicza „Impuls”, Kraków 2009.

Błeszyński J. Autyzm a niepetnosprawność intelektualna i opóźnienie w rozwoju. Skala Oceny Zachowań Autystycznych, Wydawnictwo HARMONIA UNIWERSALIS, Gdańsk 2011.

Cotugno A.J. Terapia grupowa dla dzieci z zaburzeniami ze spectrum autyzmu. Rozwijanie kompetencji i umiejętności społecznych, Wydawnictwo Fraszka Edukacyjna, Warszawa 2011.

Diagnostic and statistical manual of mental disorders. Fifth edition, (DSM-5), American Psychiatric Association, APA, Washington DC 2013.

Diagnoza zaburzeń ze spektrum autyzmu, red. Goldstein S., Naglieri J., A., Ozonoff S., Wydawnictwo Uniwersytetu jagiellońskiego, Kraków 2017.

Frith U., Autyzm. Wyjaśnienie tajemnicy, Gdańskie Wydawnictwo Psychologiczne Gdańsk 2008.

Jagielska G., Objawy autyzmu dziecięcego, [w:] Autyzm i zespót Aspergera, red. J. Komender, G. Jagielska, A. Bryńska, Wydawnictwo Lekarskie PZWL, Warszawa 2009.

Jaklewicz H., Autyzm dziecięcy, [w:] Psychiatria wieku rozwojowego, red. A. Popielarska, M. Popielarska, Wydawnictwo Lekarskie PZWL, Warszawa 2000.

Kutscher M.L., Glick J., Zaburzenia integracji sensorycznej, [w:] Dzieci z zaburzeniami taczonymi, red. L.M. Kutscher, T. Attwood, R.R. Wolff, Wydawnictwo K.E.LIBER, Warszawa 2007.

Markiewicz K., Charakterystyka zmian w rozwoju umysłowym dzieci autystycznych, Wydawnictwo Uniwersytetu Marii Curie-Skłodowskiej, Lublin 2007.

Meng-Chuan L., Lombardo, M.V., Chakrabarti, B., Baron-Cohen, S., Subgrouping the Autism "Spectrum", Reflections on DSM-5. PLOS Biology, 2013, 11(4).

Osterling J., Dawson D., Early recognition of children with autism: A study of first brithday home videotapes, "Journal of Autism and Developmental Disorders" 1994, 24.

Pisula E., Autyzm - fakty, wattliwości, opinie, Wydawnictwo WSPS, Warszawa 1993.

Pisula E., Autyzm u dzieci. Diagnoza, klasyfikacja, etiologia., Wydawnictwo naukowe PWN, Warszawa 1999.

Pisula E., Autyzm u dzieci. Diagnoza, klasyfikacja, etiologia, Wydawnictwo PWN, Warszawa 2000.

Pisula E., Małe dziecko z autyzmem, diadnoza i terapia, Gdańskie Wydawnictwo Psychologiczne, Gdańsk 2005.

Pisula E., Zaburzenia komunikacji u dzieci z autyzmem, [w:] Kiedy mózg pracuje inaczej... - postrzeganie, ruch, emocje, komunikacja, "Zeszyty Naukowe” 6 na Międzynarodowej Konferencji org. Przez Ogólnopolską Fundację na rzecz Dzieci Niepełnosprawnych „Promyk Słońca”, Wrocław, 5 grudnia 2008.

Pisula E., Autyzm. Przyczyny, symptomy, terapia, Wydawnictwo Harmonia, Gdańsk 2010. 
Pisula E., Wspomaganie osób z zaburzeniami należącymi do autystycznego spektrum w perspektywie psychopatologii rozwojowej, [w:] Psychologia rozwoju człowieka, red. J. Trempała, Wydawnictwo PWN, Warszawa 2011.

Pisula E., Od badań mózgu do praktyki psychologicznej AUTYZM, Wydawnictwo GWP, Sopot 2012.

Piszczek M., Kwestionariusz oceny kompetencji emocjonalno-społecznej (KOKE-S) wysoko funkcjonujących autystów i dzieci z zespołem Aspergera (część pierwsza), "Rewalidacja. Czasopismo dla nauczycieli i terapeutów" 2010, nr 1(27).

Randall P., Parker J., Autyzm. Jak pomóc rodzinie, Gdańskie Wydawnictwo Psychologiczne, Sopot 2010.

Robins D.L., Fein D., Barton M.L., Green J.A., The Modified - Checklist for Autism in Toddlers: An initial study investigating the early detection of autism and pervasive developmental disorders, "Journal of Autism and Developmental Disorders" 2001, 31(2).

Rynkiewicz A., Kulik M., Wystandaryzowane, interaktywne narzędzia do diagnozy zaburzeń ze spektrum autyzmu, a nowe kryteria diagnostyczne DSM-5, „Psychiatria” 2013, 10, nr 2.

Senator D., Przejawy autyzmu w pierwszym roku życia, „Pediatria Polska” 2006, nr 2.

Sigman M., Dijamco A., Gratier M., Rozga A., Early detection of core deficits in autism, „Mental Retardation and Developmental Disabilities Research Reviews" 2004, 10.

Skórczyńska M., Wczesne diagnozowanie autyzmu - perspektywy i dylematy, [w:] Autyzm Na granicy zrozumienia, red. B. Winczura, Oficyna Wydawnicza „Impuls”, Kraków 2009.

Skórczyńskka M., Autyzm a opóźnienie rozwoju, [w:] Dzieci z zaburzeniami łączonymi. Trudne ścieżki rozwoju, red. B. Winczura, Oficyna Wydawnicza „Impuls”, Kraków 2012.

Steiner A., Goldsmith T.R., Snow A.V, Chawarska K., Practitioner's Guide to Assessment of Autism Spectrum Disorders in Infants and Toddlers, "Journal of Autism and Developmental Disorders" 2012, 42(6).

Stone W.L., Coonrod E.E., Ousley O.Y., Brief report: Screening tool for autism in 2-yearolds (STAT): Development and preliminary data, "Journal of Autism and Developmental Disorders" 2000, 30(6).

Stone W.L., Lee E.B., Ashford L. i wsp., Can autism be diagnosed accurately in children under 3 years?, "Journal of Child Psychology and Psychiatry" 1999, 40(2).

Teitelbaum O., Teitelbaum P., Czy twoje dziecko ma autyzm? Jak rozpoznawać najwcześniejsze oznaki autyzmu, Wydawnictwo Harmonia Universalis, Gdańsk 2012.

Werner E., Dawson G., Munson J., Osterling J, Variation in early developmental course in autism and its relations with behavioral outcome at 3-4 years of age, "Journal of Autism and Developmental Disorders" 2005, 35. 
Wiekiera E., Strategia postępowania z dziećmi autystycznymi, Przekład z "Engagement”, Poradnik praktyczny dla rodziców, Wydawnicwo Krajowe Towarzystwo Autyzmu Oddział w Krakowie, Kraków 1995.

Winczura B., Autyzm, autyzm atypowy a schizofrenia wczesnodziecięca, [w:] Dzieci $z$ zaburzeniami łączonymi. Trudne ścieżki rozwoju, red. B. Winczura, Oficyna Wydawnicza „Impuls”, Kraków 2012.

Wing L., Zwiąek między zespołom Aspergera i autyzmem Kannera, [w:] Autyzm i zespót Aspergera, red. U. Frith, Wydawnictwo Lekarskie PZWL, Warszawa 2005.

Wolski A., Diagnoza autyzmu u matego dziecka - implikacje do pracy w rodzinie, "Rewalidacja. Czasopismo dla nauczycieli i terapeutów" 2010, nr 2(28). 